\title{
Analysis of factor V Leiden and prothrombin mutations in patients with suspected thrombophilia in São Paulo state-Brazil
}

\author{
Análise da mutação no fator $V$ de Leiden e na protrombina \\ em pacientes do estado de São Paulo, Brasil
}

Marcos Edgar Herkenhoff ${ }^{1}$; Rodrigo Gaulke²; Vanessa Rosália Remualdo33; Carlos André da Veiga Lima Rosa ${ }^{4}$

\begin{abstract}
Introduction: Prothrombin (factor II) is a thrombin precursor, which induces fibrin formation. A mutation in the prothrombin gene (G20210A) has been described, which is directly associated with high prothrombin levels, hence thrombophilia. G1691A mutation in the factor $\mathrm{V}$ Leiden (FVL) gene occurs on exon 10, one of the main cleavage sites for protein $\mathrm{C}$ activation, resulting in protein alteration. Objective: To identify and estimate the genotype frequency of the three possible genotypes and the frequency of the two existing alleles in the FVL and prothrombin genes in patients with suspected thrombophilia in the state of Sao Paulo. This study may provide more literature and reference data on the incidence of prothrombin genotypes among individuals in Brazil. Material and methods: Analysis of point mutation by real time polymerase chain reaction (RT-PCR). Results: We obtained a total of 100 individuals, from which 94\% had the homozygous $\mathrm{G}$ genotype. Only $6 \%$ had heterozygous genotype and there was no individual with the homozygous genotype $\mathrm{A}$ for FVL gene. As to the prothrombin gene, the frequency was $97 \%$ for homozygous $\mathrm{G}$ genotype and $3 \%$ for the heterozygous genotype. There was no patient with the homozygous A genotype. Conclusion: This study demonstrated that the genotype identification of these genes is advisable for patients with suspected thrombophilia in this region.
\end{abstract}

Key words: factor V Leiden; G1691A mutation; prothrombin; G20210A mutation; real-time PCR; SNP.

\section{INTRODUCIION}

Thromboembolic diseases, due to their cosmopolitan character, are among the most frequent causes of morbidity, incapacitation and mortality, with a general incidence of one in 1,000 individuals annually ${ }^{(15,20)}$. Venous and arterial thromboembolism is a hereditary or acquired disease that affects proteins from the anticoagulant system, thus leading to the formation of thrombi. Hereditary thrombophilias are generally caused by mutations in the genes that codify coagulation factors. G1691A mutation in factor V Leiden (FVL) and G20210A mutation in the prothrombin gene are the most prevalent causes of hereditary thrombosis ${ }^{(4,14,27)}$.
FLV mutation consists in the exchange of guanine $(G)$ for adenine (A) at nucleotide position1691 of FLV gene, which is located in exon 10. Thus, it results in the exchange of arginine (Arg) for glutamine (Gln) at position 506 of the protein, one of the main cleavage sites for protein $\mathrm{C}$ activation ${ }^{(16)}$. Consequently, this site has two alleles: allele $\mathrm{G}$ or non-mutant allele and allele A or mutant allele. The resistance to activated protein $\mathrm{C}$, which is caused by the loss of FVL cleavage, generates hyper coagulopathy, hence increasing the risk to venous thrombosis ${ }^{(4)}$. The hereditary activated protein $\mathrm{C}$ resistance has been regarded as the main cause of most venous thrombosis cases. Moreover, 95\% of APCR are associated with G1691A mutation in exon 10 of factor $\mathrm{V}$ gene ${ }^{(2,6)}$.

First submission on 13/07/12; last submission on 14/02/13; accepted for publication on 14/03/13; published on 20/06/13

1. Attending Master's in Animal Science (Genetic area) at Universidade do Estado de Santa Catarina (UDESC); veterinarian.

2. Graduate student in Biomedicine at Uniasselvi; technician in Genetic Analysis at Genolab.

3. Doctor in Pathology by Universidade de São Paulo (USP); scientific director at Genolab.

4. Doctor in Genetics and Molecular Biology by Universidade Federal do Rio Grande do Sul (UFRHS); professor of Genetics at Centro de Educação Superior da Região Sul (CERES)-UDESC. 
Prothrombin or coagulation factor II is a blood protein synthesized in the liver in the presence of vitamin K. Moreover, it is a thrombin precursor, which induces the formation of fibrin at the end of the coagulation cascade. It is also involved in coagulation control mechanisms, binding to thrombomodulin and activating protein $\mathrm{C}$, which also plays a fundamental role in anticoagulant balance ${ }^{(20)}$. The gene responsible for prothrombin contains approximately 21,000 pb, including 14 exons and 13 introns, located near the cetromere on chromosome $11^{(29)}$.

In 1996, a mutation in the region 3' of the prothrombin gene was described (G20210A), which is closely associated with high prothrombin levels in the blood. Therefore, it is reported as medium risk to the formation of venous thrombosis. This allelic variant comprises a point mutation in which $\mathrm{G}$ replaces nitrogenous base $\mathrm{A}$ at nucleotide 20210 near the cleavage site of messenger ribonucleic acid precursor (mRNA) where the poly-A tail is added. This mutation is associated with a rise in mRNA stability and plasma concentration of prothrombin, which seems to be the mechanism that predisposes to the occurrence of thrombosis ${ }^{(20)}$.

FVL mutation is present in several Caucasian populations and the prevalence of the heterozygous genotype varies from $2 \%$ to $13 \%$. Furthermore, it is extremely rare among Africans, Chinese, Japanese, native Americans and South Asians ${ }^{(3)}$. The mutation in the prothrombin gene affects $1 \%$ to $3 \%$ of the Caucasian population, with a 2.8 fold higher risk of thrombosis. This mutation has not been detected among Afro-descendant or Asian patients to date, which indicates that in these groups the mutation is infrequent or extremely rare ${ }^{(1,11,24,29)}$. Thus, this study had the objective to identify and estimate the frequency of three possible genotypes as well as the frequency of the two alleles present in factor $\mathrm{V}$ Leiden and prothrombin genes among patients with suspected thrombophilia in the state of São Paulo. This investigation may provide further literature and reference data on the incidence of prothrombin genotypes among individuals in Brazil.

\section{MATERIAL AND METHODS}

\section{Material collection}

In the present investigation, samples of peripheral blood were collected and sent to laboratories under contract with Genolab (Blumenau-SC), located in the state of São Paulo. The samples were collected according to the following protocol: samples kept at $4^{\circ} \mathrm{C}$ for up to three days; no orientation as to patient's preparation; $5 \mathrm{ml}$ of peripheral blood collected in tubes containing ethylenediaminetetraacetic acid (EDTA).

\section{Deoxyribonucleic acid (DNA) extraction and amplification}

We applied the phenol-chloroform extraction method for the isolation of $\mathrm{DNA}^{(23)}$. For the amplification of researched genetic material, we applied real time polymerase chain reaction (RT-PCR) with Taqman ${ }^{\circledR}$ probe and reagent concentrations were according to the technical specifications (Applied, Foster City, CA).

RT-PCR is a method that allows the quantification of genetic amplification products with the follow-up of PCR reaction in all phases and cycles. Accordingly, it dispenses with the use of conventional electrophoresis, optimizing the process ${ }^{(8)}$. The advantage of RT-PCR relies on the fact that it offers a higher sensibility when compared with conventional PCR, allowing the detection of low concentrations of genetic material in the sample ${ }^{(8)}$.

\section{Report analysis}

We analyzed the results from exam reports on FLV and prothrombin genes from Genolab database from February 2008 to March 2012. The sample comprised 100 individuals with suspected thrombophilia. As the Brazilian population is highly mixed, there was no separation into ethnic groups.

After evaluating the reports, the genotypic and allelic frequencies were assessed.

\section{RESULTS}

$10 \%$ of the patients from the total sample were male, whereas $90 \%$ were female. The higher number of exams among female patients is due to the fact that thrombophilia is associated with gestation problems, including miscarriages in the first trimester ${ }^{(19)}$.

94\% of the total individuals presented homozygous genotype G. There was no individual for homozygous genotype A and 6\% presented heterozygous genotype for FLV gene. As to prothrombin gene, $97 \%$ had homozygous genotype $\mathrm{G}$. There was no individual with homozygous genotype $\mathrm{A}$ and $3 \%$ had heterozygous genotype

(Table 1).

TABLE 1 - Genotypic frequency of FVL and prothrombin genotypes in the studied populations

\begin{tabular}{ccc}
\hline & FVL (\%) & Prothrombin (\%) \\
\hline Homozygous G & 94 & 97 \\
Heterozygous & 6 & 3 \\
Homozygous A & 0 & 0 \\
\hline
\end{tabular}

FVL: factor V Leiden. 
As to allelic frequencies, the following results were yielded: 97\% for allele $\mathrm{G}$ and $3 \%$ for allele A in the FLV gene; $98.5 \%$ for allele $\mathrm{G}$ and $1.5 \%$ for allele $\mathrm{A}$ in the prothrombin gene (Table 2).

TABLE 2 - Allelic frequency of FVL and prothrombin alleles in the studied population

\begin{tabular}{ccc}
\hline & FVL (\%) & Prothrombin (\%) \\
\hline Allele G & 97 & 98.5 \\
Allele A & 3 & 1.5 \\
\hline
\end{tabular}

FVL: factor V Leiden

\section{DISCUSSION}

In a study developed in Pernambuco, 39 individuals with mutation (13.3\%) were detected ${ }^{(21)}$. Similarly, our research demonstrated an expected frequency in Caucasians, despite the fact that our population is ethnically mixed. In comparison with the investigation from Ramos et al. ${ }^{(21)}$, another study also conducted in Pernambuco showed a frequency of $17.8 \%$ for the heterozygous genotype and $1.7 \%$ for homozygous $\mathrm{A}^{(17)}$. This variation may have occurred due to the fact that the researchers used PCR method followed by restriction fragment length polymorphism RFLP-PCR. Oliveira Filho et al. ${ }^{(17)}$ applied RT-PCR, which is admittedly more sensitive than the previous one ${ }^{(13)}$. Nevertheless, Oliveira Filho et al. compared the efficacy of both techniques (RFLP-PCR and RT-PCR) and the results did not provide any significant difference.

A study developed by Soares et al. ${ }^{(26)}$, in Minas Gerais, demonstrated a heterozygous rate of $1.9 \%$. Another one conducted by Silva Filho et al. ${ }^{(25)}$ revealed a rate of $0.7 \%$ and $3.6 \%$ in the population of Rio de Janeiro. Another research carried out by Palomo et al. ${ }^{(18)}$ with the population from the central-south region of Chile showed a mutation rate of $1.25 \%$. Accordingly, these studies presented a much lower rate in comparison with our results, which revealed a rate of $6 \%$ for the detection of heterozygous individuals.

As to the mutation in the prothrombin gene, in the study developed in Pernambuco, the genotypic frequency for the heterozygous genotype was $6 \%{ }^{(22)}$, whereas herein we demonstrated a higher frequency for the same genotype. The research carried out in the central-south region of Chile with a non-native population showed a frequency of 1.33\% for the same genotype ${ }^{(18)}$, thus a much lower frequency in comparison with our results. Another investigation carried out in Belém-PA demonstrated a frequency of $2 \%$ for heterozygous genotype ${ }^{(28)}$, relatively similar to the results demonstrated herein.

Another investigation carried out with the general population and cases of severe widespread thrombosis in Mediterranean Spain revealed a frequency of $5.3 \%$ for heterozygous genotype in both populations $^{(7)}$. The same investigation conducted in Minas Gerais yielded a frequency of $5.9 \%$ for heterozygous genotype ${ }^{(9)}$. Thus, in comparison with these studies, the population of São Paulo produced very similar results for the frequency of heterozygous genotype in the FLV gene.

The mutation in the prothrombin gene yielded a frequency of $3 \%$ for heterozygous genotype. This mutation is more commonly detected in the Caucasian population and it has not been found among Afro-descendant and Asian patients ${ }^{(11,29)}$.

In the study developed in Pernambuco, the genotypic frequency for the heterozygous genotype was $6 \%$, contrasting with a higher frequency for the same genotype in the sample from São Paulo. The same study conducted in the central-south region of Chile with a non-native population showed a frequency of $1.33 \%$ for the same genotype ${ }^{(18)}$, hence a much lower frequency in comparison with our results.

The investigation conducted in Belém-PA demonstrated a frequency of $2 \%$ for heterozygous genotype ${ }^{(28)}$. In contrast, the present study showed a relatively higher frequency. The study conducted with the general population and cases of severe widespread thrombosis in Mediterranean Spain showed a frequency of 5.3\% for heterozygous genotype in both populations ${ }^{(7)}$. The same study conducted in Minas Gerais showed a frequency of $5.9 \%$ for the heterozygous genotype. Consequently, in comparison with these studies, the population of São Paulo presented lower results in the frequency of heterozygous genotype in the prothrombin gene.

In a study developed by Herkenhoff et $a l^{(10)}$, the frequency of heterozygous genotype was 7.26\% in the state of Paraná and 15.13\% in the state of Santa Catarina, respectively. The results yielded herein were lower in comparison with those from Paraná and significantly lower in comparison with those from Santa Catarina. As the south of Brazil was historically colonized by Europeans, mainly from Italian and German origins, it was expected that this investigation revealed a lower heterozygous genotype frequency as to the prothrombin gene. Furthermore, all studies mentioned above, with exception of that conducted by Herkenhoff et al. ${ }^{(10)}$, applied RFLP-PCR method, with lower sensitivity when compared with RT-PCR. This may account for the low frequency of heterozygous genotype in the studies previously mentioned.

\section{CONCLUSION}

RT-PCR has a higher sensitivity in relation to other techniques applied in this study, resulting in different heterozygous genotype 
figures. Therefore, it is recommended for the identification of point mutations or single nucleotide polymorphism (SNP).

Due to the fact that the literature does not provide enough information on this mutation in Brazil, these data will become a research tool for future reference, contributing to the database in Brazil.
The present investigation validated that the identification of this genotype is advisable for patients with suspected or confirmed thrombophilia, mainly considering the fact that our results substantiate a considerable frequency of mutations in the studied population.

\section{RESUMO}

Introdução: A protrombina (fator II) é a precursora da trombina, que induz a formação de fibrina. Foi descrita uma mutação no gene da protrombina (G20210A), associado diretamente a altos niveis de protrombina no sangue e, consequentemente, a trombofilia. A mutação G1691A no gene do fator V de Leiden (FLV) localiza-se no éxon 10, resultando na alteração da proteína, um dos principais sítios de clivagem para ativação da proteina C. Objetivos: Identificar e estimar a frequência genotípica dos três possíveis genótipos, assim como estimar a frequência dos dois alelos existentes no gene do FLV ena protrombina em pacientes com suspeita de trombofilia no estado de São Paulo. Este estudo poderá fornecer mais dados para a literatura e para consulta da incidência dos genótipos da protrombina em indivíduos no Brasil. Material e métodos: Análise de mutação pontual por reação em cadeia da polimerase em tempo real (RT-PCR). Resultado: Obtivemos o número de 100 indivíduos e, desse total, 94\% possuíam o genótipo para homozigoto G; apenas 6\%, genótipo beterozigoto; nenbum indivíduo foi encontrado com genótipo bomozigoto A no gene do FLV. No gene da protrombina, a frequência foi de 97\% para o genótipo bomozigoto Ge 3\% para o genoma heterozigoto; não foi encontrado nenhum indivíduo com o genoma bomozigoto A. Conclusão: Este estudo mostrou que é recomendável a identificação do genótipo para esses genes em pacientes com suspeita de trombofilia nessa região.

Unitermos: fator V de Leiden; mutação g1691A; protrombina; mutação G20210A; PCR em tempo real; SNP.

\section{REFERENCES}

1. ARRUDA, V. R.; ANNICHINO-BIZZCCHI, J. M.; GONÇALVES, M. S.; COSTA, F. F. Prevalence of the prothrombin gene variant (nt20210A) in venous thrombosis and arterial disease. Thromb Haemost, v. 78, n. 6, p. $1430-3,1997$.

2. BERTINA, R. M. et al. Mutation in blood coagulation factor $\mathrm{V}$ associated with resistance to activated protein C. Nature, v. 369 , n. 6475 , p. 64-7, 1994.

3. BERTINA, R. M. Factor V Leiden and other coagulation factor mutations affecting thrombotic risk. Clinical Chemistry, v. 43, n. 9, p. 1678-83, 1997.

4. DAHLBÄCK, B. Blood coagulation. Lancet, v. 355, n. 9215, p. 1627, 2000.

5. DAHLBÄCK, B. New molecular insights into the genetics of thrombophilia. Resistance to activated protein C caused by Arg 506 to Gln mutation in factor $\mathrm{V}$ as a pathogenic risk factor for venous thrombosis. Thromb Haemost, v. 74, n. 1, p. 139-48, 1995.

6. DEVISSER, M. C.; ROSENDAAL, F. R.; BERTINA, R. M. A reduced sensitivity for activated protein $\mathrm{C}$ in the absence of factor $\mathrm{V}$ Leiden increases the risk of venous thrombosis. Blood, v. 93, n. 4, p. 1271-6, 1999.

7. FRANCÈS, F. et al. Comparación de las frecuencias de los alelos factor $\mathrm{V}$ Leiden (G1691A) y protrombina - G20210A entre pacientes con trombosis venosa profunda y población general mediterránea española. Rev Med Chile, v. 134, p. 13-20, 2006.
8. GINZINGER, D. G. Gene quantification using real-time quantitative PCR: an emerging technology hits the mainstream. Exp Hematol, v. 30, p. 503-12, 2002.

9. GUIMARÃES, S.P.; SOARES; J. B. B.; OLIVEIRA, V. C.; PARDINI, V. C.; FERREIRA, A. C. S. Mutações predisponentes à trombofilia em indivíduos de Minas Gerais-Brasil com suspeita clínica de trombose. Rev Bras Hematol Hemoter, v. 31, n. 1, p. 19-24, 2009.

10. HERKENHOFF, M. E. et al. Análise da mutação G20210A no gene da protrombina (fator II) em pacientes com suspeita de trombofilia no sul do Brasil.J Bras Patol Med Lab, v. 48, n. 2, p. 85-9, 2012.

11. HIRA, B.; PEGORARO, R. J.; ROM, L.; MOODLEY, J. Absence of factor V Leiden, thrombomodulin and prothrombin gene variants in Black South African women with pre-eclampsia and eclampsia. BJOG, v. 110, p. 327-8, 2003.

12. LANE, D. A.; GRANT, P. J. Role of hemostatic gene polymorphisms in venous and arterial thrombotic disease. Blood, v. 95, n. 5, p. 1517-32, 2000.

13. LODISH, H. Biologia celular e molecular. 5. ed. São Paulo: Artmed, 2005. $1058 \mathrm{p}$.

14. MAHONNET, F. et al. Absence of factor V Leiden mutation and low prothrombin G20210A mutation prevalence in a healthy Moroccan population. Thromb Haemost, v. 88, n. 1, p. 1073-4, 2002.

15. MATEO, J.; OLIVER, A.; BORRELL, M.; SALA, N.; FONTCUBERTA, J. Increased risk of venous thrombosis in carriers of natural anticoagulant 
deficiencies: results of the family studies of the Spanish Multicenter Study on Thrombophilia (EMET study). Blood Coagul Fibrinolysis, v. 9, n. 1, p. 71-7, 1998 .

16. NORSTRØM, E.; THORELLI, E.; DAHLBÄCK, B. Functional characterization of recombinant FV Hong Kong and FV Cambridge. Blood, v. 100, p. 524-30, 2002.

17. OLIVEIRA FILHO, A. B. et al. Discriminação alélica do fator $V$ da coagulação por PCR em tempo real: diagnóstico simples e preciso. Rev Bras Hematol Hemoter, v. 31, n. 1, p. 25-8, 2009.

18. PALOMO, I.; SEGOVIA, F.; PARRA, D.; ALARCÓN, M.; ROJAS, E. Low prevalence of Factor V Leiden and the prothrombin G20210A mutation in a healthy population from central-south region of Chile. Rev Bras Hematol Hemoter, v. 31, n. 3, p. 143-6, 2009.

19. PIHUSCH, B. Thrombophilic gene mutations and recurrent spontaneous abortion: prothrombin mutation increases the risk in the first trimester. Am J Reprod Immunol, v. 46, n. 2, p. 124-31, 2001.

20. POORT, S. R.; ROSENDAAL, F. R.; REITSMA, P. H.; BERTINA, R. M. A common genetic variation in the 3 ' untranslated region of the prothrombin gene is associated with elevated prothrombin levels and an increase in venous thrombosis. Blood, v. 88, n. 10, p. 3698-703, 1996.

21. RAMOS, C. P. S. et al. Freqüência do fator V Leiden em indivíduos sob investigação de trombofilia, Recife, Pernambuco, Brasil. Rev Bras Hematol Hemoter, v. 28, n. 2, p. 131-4, 2006.
22. RAMOS, C. P. S. et al. Protrombina mutante em indivíduos sob investigação de trombofilia.J Bras Patol Med Lab, v. 44, n. 2, p. 79-82, 2008. 23. SAMBROOK, J.; FRITSCH, E. F; MANIATIS, T. Molecular cloning a laboratory manual. 2. ed. USA: Cold Spring Harbor Laboratory Press, 1989, 1886 p.

24. SELIGSOHN, U.; LUBETSKY, A. Genetic susceptibility to venous thrombosis. N Engl J Med, v. 344, n. 16, p. 1222-31, 2011.

25 . SILVAFILHO, I. L. The frequency of $\beta$-ßglobin gene haplotypes, $\alpha \alpha \alpha \alpha$ $\alpha$-thalassemia and genetic polymorphisms of methylenetetrahydrofolate reductase, factor $\mathrm{V}$ Leiden and prothrombin genes in children with sickle cell disease in Rio de Janeiro, Brazil. Rev Bras Hematol Hemoter, v. 32 , n. 1, p. 76-8, 2009.

26. SOARES, A. L. et al. Avaliação da incidência das mutações G1691A no gene do fator $\mathrm{V}$ (fator $\mathrm{V}$ Leiden) e G20210A no gene da protrombina em pacientes com diabetes mellitus tipo 2. Rev Bras Hematol Hemoter, v. 27, n. 3, p. 192-6, 2005.

27. SOUZA, S. S.; FERRIANI, R. A.; PONTES, A. G.; ZAGO, M. A.; FRANCO, R. F. Factor V Leiden and factor II G20210A mutations in patients with recurrent abortion. Hum Reprod, v. 14, n. 10, p. 448-50, 1999.

28. YOSHIOKA, F. K. N.; ARAÚJO, A. G.; TAVELLA, M. H.; HAMOY, I. G.; GUERREIRO, J. F. Prevalence of hereditary risk factors for thrombophilia in Belém, Brazilian Amazon. Genet Mol Biol, v. 29, n. 1, p. 38-40, 2006.

29. ZIVELIN, A. et al. A Single genetic origin for the common prothrombotic G20210A polymorphism in the prothrombin gene. Blood, v. 92, n. 4, p. 1119-24, 1998

\section{MAILING ADDRESS}

Marcos Edgar Herkenhoff

Marechal Floriano Peixoto, 425; Centro; CEP: 89010-500; Blumenau-SC, Brazil; Tel.: (47) 3326-1177; e-mail: marcos.herkenhoff@gmail.com. 